\title{
Érsek Attila
}

\section{Digitális eszközök tanulókra vonatkozó kognitív hatásainak feltáró jellegü kismintás kutatásai}

\section{Bevezetés}

A köznevelési intézményekben tervezett digitális átállás megvalósításához elengedhetetlenek a témában végzett helyzetképfeltárást megvalósító kutatások. A digitális pedagógiai kultúra állapotának megismeréséhez szükséges a tanulók eszközhasználati tevékenységének felmérése, hisz az képet ad a pedagógusok tanulásszervezési eljárásairól is.

Jelen tanulmány segíti a pedagógusokat a digitális átállás során a tájékozódásban, hisz a digitális eszközök oktatási alkalmazásáról végzett feltáró jellegü vizsgálatát írja le úgy, hogy egyrészt a pedagógusok és diákok (az ő adataik állnak rendelkezésre elsősorban) körében végzett kérdőíves vizsgálatot, másrészt a digitális eszközök tanulókra vonatkozó kognitív hatásait helyezi a fókuszba. A tanulók körében végzett vizsgálatok közvetetten információt szolgáltatnak a pedagógus célcsoport digitális pedagógiáról való gondolkodásának mikéntjére, hisz konkrét alkalmazások ismertségére és használatára vonatkozó elemek vannak a kérdések között.

A mérés eredményei, illetve egy nemzetközi tapasztalatcsere során gyüjtött megfigyelési eredmények kijelölik azokat a fejlesztési pontokat a pedagógusok számára, amelyek a nemzetközi trendekkel összhangban vannak. A tapasztalatok hozzájárulhatnak, egyben előkészíthetik a pedagógusok körében végzett nagymintás online kérdőív néhány kérdésének a fókuszpontjait a tanulási környezet, az osztálytermi tevékenységek, tanulásszervezés és módszertan, értékelés, tartalom- és tananyag-közvetítés területén. Az elméleti keretek területét csak olyan mértékben érintem, amely feltétlen szükséges a téma tárgyalásához. 
Korábbi feltárt kutatásaim elemeire támaszkodom, emellett kiegészítem aktuális kutatási eredményekkel is a kismintás méréseket.

\section{A web 2.0 definiálása, csoportosítása}

A web 2.0 felhasználása a tanítási-tanulási folyamatban kiemelt feladatnak tekinthető, mert segíti a digitális kompetencia fejlesztésének területén a pedagógusi munkát. Az egyik feladat a diákok tanulásának segítése a különböző alkalmazások segítségével. A rövid összefoglalásban - kismintás kutatásokra támaszkodva - az adott területhez kapcsolódó helyzetfeltárásra szorítkozom. Példáimat a történelemhez kapcsolom, de az eszközhasználat és a web 2.0-ás „világ” felhasználásának tantárgytól független elemei hasznosíthatók más szakos pedagógusok számára is.

Z. Karvalics (2009) a következöképpen határozta meg a web 2.0 fogalmát: „A Web 2.0 egy jelenség-együttes megnevezése. Ennek a jelenség és szolgáltatásegyüttesnek két közös vonása van: az interakció és a tartalommegosztás. A Web 2.0 az a változás, amikor az internethasználók az addigi fogyasztóból (tartalom)szolgáltatóvá váltak. Az addig egyirányú webes kommunikáció kétirányúvá vált - rendkívül egyszerü lett tartalmak, képek, szövegek, linkek, videók, események és kapcsolatok megosztása. Ez a változás az emberi interakciók forradalmát inditotta el. A Web 2.0 tehát olyan internetes szolgáltatások gyüjtöneve, amelyek elsösorban a közösségre épülnek, azaz a felhasználók közösen készítik a tartalmat vagy megosztják egymás információit."

Egy web 2.0-ás csoportosítási lehetőséget ismertetek Námesztovszki és társai alapján, ${ }^{1}$ kiegészítem saját példákkal, illetve a megszünt vagy háttérbe szorult szolgáltatásokat nem teszem be a példák közé (pl. iWiw, Delicious). A fenti meghatározásnál ez a csoportosítás tágabban értelmezi a web 2.0 elemeit, ezt a fogalmi keretet alkalmazom én is a továbbiakban:

- Blogok (pl. WordPress, Blogspot)

- Közösségi tartalomszerkesztés (pl. wiki)

- Videómegosztók (pl. YouTube, Videa, Indavideo)

- Képmegosztók (pl. Picasa, Flickr)

- Közösségi oldalak (pl. Facebook)

- Online dokumentumszerkesztés (pl. GoogleDocs, Google Drive)

\footnotetext{
${ }^{1}$ A felsorolás összeállításához felhasznált elektronikus kérdőív: A web 2.0-ás eszközök alkalmazása (a kutatás vezetője dr. Námesztovszki Zsolt)
} 
- Microblogok (pl. Twitter)

- Podcast

- e-Portfóliók

- Közösségi könyvjelzők (pl. Pearltrees)

- Online játékok, környezetek (pl. Kahoot, Socrative, Second Life)

- Online prezentációk (pl. Prezi, Slideshare)

- Online gondolattérképek (pl. MindMeister, bubbl.us, Mindomo, VUE)

- e-Learning keretrendszer (pl. Moodle, Edmodo, Neo LMS stb.)

A pedagógusok módszertani és pedagógiai lehetőségeik bővítésére alkalmazhatják a web 2.0-ás eszközöket a digitális kultúra fejlesztése, a tudásmegosztás, a közösségi tanulás és az egymástól való tanulás támogatása érdekében. Az iskolákban komoly kihívást jelent az M-DOS céljainak bevezetése a mindennapi gyakorlatba. Néhány területet kiemelek, amelyek a 21 . századi készségfejlesztés és a tanulói digitális kompetencia fejlesztése kapcsán előtérbe kerülnek a módszertani alkalmazások során: kutatásalapú tanulás, problémaalapú tanulás, projektmódszer, tevékenykedtetés, játékosítás (gamifikáció). Bár az oktatási eszközök fontosak, nem ezek a központi kérdései a tanulásnak, a tanulók és a tanárok új szerepei alakítják a tanulási környezetet, fontos a diákok együttműködése és a valódi problémák megoldásának ösztönzése.

Tulajdonképpen a fentiek megvalósításán is dolgozik a Digitális Módszertani Központ szakmai csapata. Elkészült a Digitális Oktatási Stratégia, amely átfogóan és korszerüen közelíti meg a digitális kompetencia fejlesztésének folyamatát. A digitális módszertani megoldások elterjesztésének hazai gyakorlatát nagymértékben segítette/segíti dr. Főző Attila László és Nagy Regina, valamint munkatársaik tevékenysége (pl. a Digitális témahét bevezetése, terjesztése; Code Week; e-Twinning projektek; webináriumok; képzések stb.).

Szeretném felhívni a figyelmet a téma kapcsán arra a tanulási eszközök listára, amely Jane Hart nevéhez kapcsolódik, aki immár 12. alkalommal tette közzé 2018-ban elvégzett vizsgálatának eredményeit. ${ }^{2}$ Hart meghatározása szerint tanulási eszköznek minősül minden olyan szoftver, online eszköz vagy szolgáltatás, amit használhat az egyén személyes vagy szakmai tanulásához, az oktatáshoz és képzéshez, illetve e-learning létrehozására. A lista tehát nem csupán

\footnotetext{
${ }^{2}$ Hart, J. (2018). Top 200 Tools for Learning 2018. Letöltés dátuma: 2019. 02. 22. , Forrás: https://www.toptools4learning.com/home/
} 
a web 2.0-ás eszközöket tartalmazza, hanem azokat is, amelyek a fenti meghatározás alapján segítik a tanítást-tanulást. 2016-ban a listát 100-ról 200 eszközre bővítették, és azóta 3 allistát is létrehoztak a top 100 kategóriában: ezek a személyes és szakmai tanulás eszközei (PPL 100), a munkahelyi tanulás eszközei (WPL 100) és az oktatási eszközök (EDU 100). Az oktatási eszközök 10-es listája és rövid leírása a 2018 szeptemberi adatok alapján a következő:

1. PowerPoint - prezentációs szoftver

2. YouTube - videomegosztó platform

3. Word - szövegszerkesztő szoftver

4. Google Docs/Drive - felhőalapú irodai csomag és tárolás

5. Google Search - webes keresőmotor

6. Kahoot - osztálytermi visszajelző eszköz

7. Padlet - online tábla (kollaborációhoz)

8. Canva-grafikai tervezőeszköz

9. WhatsApp - üzenetküldő alkalmazás

10. Zoom - videokonferencia megtartását biztosító eszköz

Az első 10 tanulási eszköz közös eleme, hogy támogatják az együttmüködő tanulást, kapcsolatot teremtenek a munka világával, összességében a 21. századi készségek kialakításnak kiváló terepei.

\section{Kismintás kutatások a web 2.0-ás tanítási-tanulási folyamatokról}

A web 2.0-ás lehetőségek gyakorlati megvalósítása mellett mikrokutatást folytattam az AgriaMedia 2014-es konferencia „Az elektronikus tananyag és rendszer-fejlesztés új megoldásai" témája körében. Az akkor készített tanulmány címe: Hatással van-e a web 2.0 a tanítási-tanulási folyamatra? Ez előkészítette a 2018-as kutatásom háttérkérdőívének egy részletét, amely információt nyújt közvetetten a pedagógusok eszközhasználati szokásairól is.

A kutatás a tanulás és a teljesítmény növelésének lehetőségeire fókuszált az IKT technológia és az elmélet segítségével. A témához kapcsolódó következtetésre térek ki ebből a tanulmányból. A web 2.0 eszközök felhasználásánál a tanári magatartást nagymértékben befolyásolják a technikai feltételek: Van-e a tanteremben tanári asztali számítógép vagy laptop? Van-e stabil internetkapcsolat? Ez 2019-ben már megvalósuló folyamatnak tekinthető. Rendelkezésre állnak-e tanulói laptopok (esetleg okostelefon, tablet)? 
Ebből következik, hogy tanórán nem mindenhol van lehetöség ennek alkalmazására. A web 2.0-ás alkalmazások eszközként felhasználhatók tehát a tanulási folyamatban, az e-learning keretrendszerek különösen hasznosak. A tanórán kívüli tanulási folyamatok esetében is hasznosak a web 2.0-ás alkalmazások.

Tanárok és diákok körében végeztem kismintás (N=55) felmérést 2014-ben, a Hart által tág értelemben használt tanulási eszközök közül 25 esetében kérdeztem meg, hogy használják-e, ismerik-e vagy nem használják, tehát nem mindegyik volt web 2.0-ás eszköz. Részben a történelem tantárgyhoz kapcsolódók a honlapok. A következőkre kérdeztem rá: Chat, Delicious, Edu 2.0 (a Neo LMS korábbi neve), Facebook, Flickr, Google Drive, GoogleDocs, MEK (Magyar Elektronikus Könyvtár), Microsoft Excel, MindMeister, Moodle, Múlt-kor történelmi portál, Picasa, Prezi, Realika, Second Life, Skype, Socrative, Sulinet portál, Történelemtanárok Egylete, Történelemtanítás, Twitter, VUE, WordPress, Youtube.

Egyáltalán nem használta az általam mért minta a következő alkalmazásokat, honlapokat: Delicious, Edu 2.0, MindMeister, Múlt-kor történelmi portál, Realika, Prezi, Second Life, Socrative, Történelemtanárok Egylete; 1 fó használta a következőket: Flickr, GoogleDocs, Történelemtanítás, VUE. Megállapítható volt akkor, hogy a tanítási-tanulási folyamatra kevés hatása volt a web 2.0-ás eszközök alkalmazásának az általam mért mintában. Ezt egy másik mérés is megerősítette 2014-ben. Az Oktatáskutató és Fejlesztő Intézet megbízásából dr. Szepesi Gáborral (Szabó Márta irányításával és Szendrei Péter segítségével) kutatást végeztünk elektronikus feladatlapok Moodle felületen történő megoldásával. A kismintás mérésben 77 diák vett részt (3 gimnáziumi osztály). Készítettünk elektronikus kérdőívet is, amelynek egyik kérdése arra vonatkozott, hogy találkozott-e már a tanuló elektronikus feladatsorral valamilyen helyzetben (1. ábra).

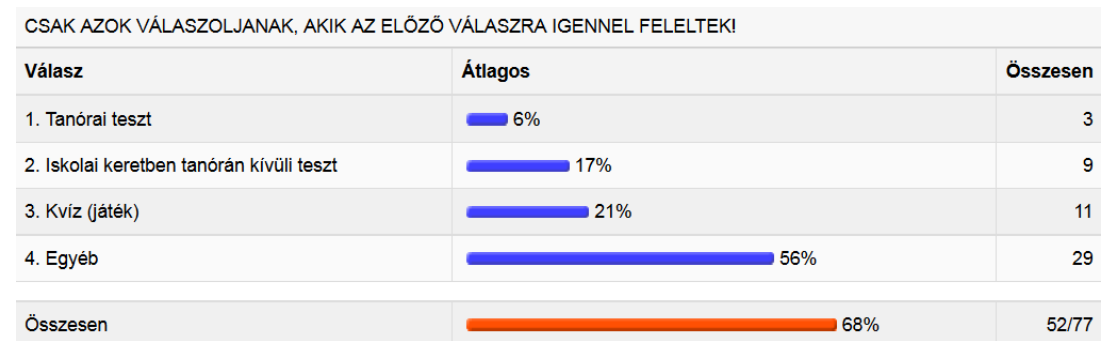

1. ábra. Elektronikus tesztek ismertsége a diákok körében (N=77) OFI felmérés 
Látható, hogy a minta 68\%-a találkozott elektronikus teszttel, de csupán a negyedét tették ki a válaszolóknak azok, akik a tanítási-tanulási folyamatban is használták: tanórán vagy iskolai keretben tanórán kívül. Ha az egész mintaszámot vesszük, akkor ennél rosszabb a helyzet.

Akkori következtetésem ez volt: A helyzet javulására akkor lehet számítani, ha a tanárképzésbe vagy továbbképzésekbe beépül a web 2.0-ás alkalmazások tanításának eszközhasználata és módszertana. A folyamatok elindultak (pl. TÁMOP 3.1.4, TIOP és EFP pályázatok, IKT szaktanácsadói képzés stb.), de rendszerszinten a kismintás mérés alapján még nem hatékony a változás, nem hat a web 2.0 a tanítási-tanulási folyamatra. Azaz jelentéktelen a digitális társadalom hatása a köznevelésben a gyerekekre és a pedagógusi tanulásszervezési eljárásokra az általam vizsgált mintákban.

A következő mérés adataihoz a 2018-as pedagógiai kísérletem során jutottam. A téma kapcsolódik a fö kutatási területemhez (az értekezésem címe: A történelmi kritikai gondolkodás kognitív elemeinek fejlesztési, mérési lehetöségei a 11-12. évfolyamos gimnáziumi tanulók körében web 2.0 tanulási környezetben), a háttérkérdőív egy részét képezik a most közzétett adatok. A tanulók által ismert, nem ismert, illetve használt tanulási eszközök elemzése során egyértelmü, hogy a korábbi kismintás méréshez képest van elmozdulás az alkalmazások, honlapok használata során, de ez nem jelentős mértékủ az 5 évvel korábbi adatokhoz képest. 
1. táblázat. Web 2.0 alkalmazások és történelmi témájú honlapok ismerete $(\mathrm{N}=152)$

\begin{tabular}{lcccccc}
\hline \hline & \multicolumn{2}{c}{ ismerem } & \multicolumn{2}{c}{ nem ismerem } & \multicolumn{2}{c}{ használom } \\
& fö & \% & fö & \% & fö & \% \\
\hline Prezi & 74 & 48,7 & 55 & 36,2 & 23 & 15,1 \\
Second Life & 11 & 7,2 & 140 & 92,1 & 1 & 0,7 \\
NEO LMS & 11 & 7,2 & 138 & 90,8 & 3 & 2 \\
Google Drive & 43 & 28,3 & 1 & 0,7 & 108 & 71,1 \\
Google Classroom & 30 & 19,7 & 115 & 75,7 & 7 & 4,6 \\
Moodle & 12 & 7,9 & 135 & 88,8 & 5 & 3,3 \\
Kahoot & 35 & 23 & 80 & 52,6 & 37 & 24,3 \\
MindMeister & 4 & 2,6 & 146 & 96,1 & 2 & 1,3 \\
VUE & 2 & 1,3 & 149 & 98 & 1 & 0,7 \\
Socrative & 16 & 10,5 & 121 & 79,6 & 15 & 9,9 \\
Redmenta & 22 & 14,5 & 109 & 71,7 & 21 & 13,8 \\
LearningApps & 32 & 21,1 & 114 & 75 & 6 & 3,9 \\
Twitter & 117 & 77 & 3 & 2 & 32 & 21,1 \\
Facebook (tanulási céllal) & 54 & 35,5 & 7 & 4,6 & 91 & 59,9 \\
Sulinet & 60 & 39,5 & 47 & 30,9 & 45 & 29,6 \\
Múlt-kor történelmi portál & 31 & 20,4 & 103 & 67,8 & 18 & 11,8 \\
Történelemtanítás online & 21 & 13,8 & 124 & 81,6 & 7 & 4,6 \\
Árkádia & 15 & 9,9 & 133 & 87,5 & 4 & 2,6 \\
Rubicon online & 32 & 21,1 & 100 & 65,8 & 20 & 13,2 \\
Századok & 12 & 7,9 & 133 & 87,5 & 7 & 4,6 \\
\hline \hline
\end{tabular}

A 152 fős mintában (213 főből válaszoltak, azaz 29\%, a minta majdnem harmada nem adott választ) az elektronikus gondolattérképet (MindMeister, VUE) nem használják a tanulók, de jelentéktelen a virtuális tanulási környezetben történő feladatvégzés is (Second Life, Neo LMS, Google Classroom, Moodle). A tanári módszertár során a gamifikáció lehetőségeit jelenleg nem használjuk ki tanárként, nagyon alacsony a LearningApps, Socrative és Redmenta ismertsége is. A Kahoot, amely a Jane Hart által végzett EDU 100-as lista 6. helyén áll, a kismintás mérésben a legismertebb oktatási visszajelző eszköz: 24,1 százalék használja. A mért alkalmazások közül a legnépszerübb a tudásmegosztásra alkalmas Google Drive $(71,1 \%)$ és a Facebook alkalmazása tanulási célra (59,9\%). A történelmi témájú honlapok közül a Rubicon online használata a leggyakoribb, de ez is alacsony értékü $(13,2)$.

Összességében tehát a kollaborációt, tudásmegosztást és a célzott ismeretszerzést támogató online felületek pedagógiai használata a tanulás támogatására a 
pedagógusok körében sem lehet magas a diákok visszajelzése alapján. Egy nagyobb mintán végzett mérés tovább tudná árnyalni, pontosítani a helyzetképet.

A módszertani lehetőségek egyike az oral history müfaja. Kutatási tényeken alapuló tananyagfejlesztés zajlik jelenleg is az MTA-SZTE Elbeszélt Történelem és Történelemtanítás Kutatócsoportban ${ }^{3}$ ezzel kapcsolatban. Az eredményeik félidős beszámolójából idézek, az összefoglalót készítette a kutatócsoport vezetője, Jancsák (2019):

Fontos, hogy „, napjaink screenager generációi számára az info-kommunikációs technikák adta lehetöségekkel éljünk az oktatás világában is, ezek az eszközök és a technika adta lehetöségek támogassák a 21. század modern iskolájának küldetését.

A csoport müködésének elsö idöszakában három, a magyar társadalom által kibeszéletlen témakörben (a II. világháborús magyar részvétel, a magyarországi Holokauszt és az 1956-os forradalom és szabadságharc témájában) fejlesztett ki szemtanúkkal, elszenvedőkkel, résztvevökkel készült interjúrészleteket felhasználó történelemórákat és vizsgálja azok alkalmazásának módozatait, valamint hatását az iskolások vélekedéseire.

A történelemtanitás kutatásának nemzetközi dimenziójában alapvetöen két szemléletmód erösödött fel az utóbbi években. Az egyik megközelités szerint a kritikai gondolkodás fejlesztésének és a forráselemzésnek kell a történelemtanitás krédójában állnia, a másik szerint a történelemtanitás a kollektiv emlékezet megörzöje. A kutatócsoport munkájával amellett érvel, hogy a két nézetrendszer együttese az, amely komoly hozzáadott értéket jelenthet a jelenleg iskolapadban nevelödö generációk késöbbi élete szempontjából, amikor a generációkon átivelö transz-történelmi értéket magáénak valló, múltunkkultúránk elemei iránt elkötelezett, tudatos állampolgári szerepre készíti fel a fiatalokat."

A kutatás során történelemtanárokkal folytattak kérdőíves és fókuszcsoportos vizsgálatokat, illetve végzös általános és középiskolás diákok körében kérdőíves vizsgálatokat. Ezekkel a helyzetfeltáró kutatásokkal mélyebb ismereteket kívántak szerezni „a fiatalok körében a történelmi múltunk eseményeiröl élö kép, a családban és a kortárscsoportokban ezekröl folyó diskurzus, illetve az IKT eszközöknek a történelemtanitásban való felhasználhatóságáról, a pedagógusok körében pedig a történelemtanitás

${ }^{3}$ Az MTA honlapján a kutatócsoport elérhetősége: https://bit.ly/2U10xFU (2019. 03.

21.) 
értékvilágáról vallott nézeteikröl, az IKT-eszközök és a digitális tartalmak alkalmazásáról és annak tapasztalatairól, illetve az IKT-kompetenciákról."

A helyzetfeltáró kutatások után partneriskolai hálózatot alakítottak ki, majd munkacsoportokban tananyagfejlesztés zajlott. A tananyagokat történész szakértőkkel, valamint az ember és társadalom müveltségterület egyetemi szakmódszertanos kollégáival lektoráltatták. 2017 őszétől kezdődött a tananyagok iskolai tesztelése, 2018 tavaszától a kísérleti tanórák (videointerjús órák) estében adatfelvételek következtek. A kutatócsoport létrehozott egy honlapot ${ }^{4}$ ahová folyamatosan töltik fel az aktuális információkat és anyagokat. Az egyik kutatási dokumentum Pászka (2016) összefoglalója.

\section{Nemzetközi tapasztalatcsere összegzése (Helsinki, Espoo)}

Az EFOP-3.2.15-VEKOP-17 „A köznevelés keretrendszeréhez kapcsolódó mérési-értékelési és digitális fejlesztések, innovatív oktatásszervezési eljárások kialakítása, megújítása" címü projekt kiemelt célja a digitális pedagógia magyarországi bevezetésének támogatása. Ennek keretében a Digitális Pedagógiai Módszertani Központ segítségével vettem részt 2018. november 5-8. között a finnországi nemzetközi tapasztalatcsere-programon. Az alábbi összefoglalást a DPMK számára készített szakmai beszámoló alapján állítottam össze. A finn középiskolákban a konstruktív pedagógia elemeit felhasználva általánosnak tekinthető az együttmüködés valamilyen felhőalapú szolgáltatásban (pl. Google Classroom, O365, Wilma stb.). Ez tantárgytól, projekttől független, az IKT eszközök réven is erős szocializációs fejlesztés történik. A pedagógiai hatása: a diákok nagyfokú önállósággal rendelkeznek, a problémahelyzeteket megoldó képességük fejlett. Természetes folyamat az IKT eszközhasználat. Kérdés esetén mernek (és lehet) a náluk lévő eszköz segítségéhez folyamodni a hiányzó ismeretelem megkeresése érdekében. A finnek a műveltségalapú oktatás helyett a kompetenciák fejlesztésére koncentrálnak. A hospitálások során látott tanulói tevékenységek a kulcskompetenciák szinte minden területét lefedték:

- anyanyelvi kommunikáció (pl. csoportban egyeztetések, prezentálás),

- idegen nyelvi kommunikáció (pl. a svéd nyelv tanulása, az angolt mindenki érti, beszéli folyékonyan),

- matematikai kompetencia (pl. programozás robotokkal),

\footnotetext{
${ }^{4}$ MTA-SZTE Elbeszélt Történelem és Történelemtanítás Kutatócsoport. Letöltés dátuma: 2019. 03.21., Forrás: http://www.eyewitness.hu/
} 
- digitális kompetencia (pl. a projektek tartalmi elemeinek készítése, információszerzés, az e-biztonság betartása, online kommunikáció, a problémafelvetés megoldása),

- szociális kompetencia (állandó együttmüködés),

- állampolgári kompetencia (pl. a svéd nyelv napjáról /november 6./ tudtak a diákok),

- kezdeményezőképesség (pl. felnőttekkel a kapcsolatfelvétel, projektötletek),

- hatékony, önálló tanulás (pl. online egyéni és csoportos problémamegoldások esetén).

$\mathrm{Az}$ Olari gimnáziumban (Espoo) a SAMR-modell (technológiai alapú megközelítési modell Puentedura, 2006) szerinti újraértelmezés (4. fázis) szerinti pedagógiai megoldásokat tapasztaltam. A tanárok menedzselték, irányították a tanulói munkát. A tanári és tanulói kompetenciák közül a megfigyelések és a szóban elhangzottak alapján lehetett azonosítani a digitális kompetenciaterületeket: információ, kommunikáció, tartalomelöállítás és problémamegoldás. Ezek közül nagyon erőteljes volt az IKT eszköz segítségével történő interakció és tartalommegosztás valamely felhőalapú szolgáltatást igénybe véve.

A látott iskolai jó gyakorlatok közül a legtöbb hozzáadott értéket egy hazai iskolában dolgozó pedagógusnak a kutatásalapú tanítás gyakorlatának átvétele jelenthet. Ezt a pedagógiai szemléletmódot ösztönzik itthon a digitális témahéthez kapcsolódó pedagógiai jó gyakorlatok is. Az észrevétlen, természetes eszközhasználatot támogatta az Olari gimnáziumban, hogy 2017 óta bevezették a saját eszközhasználatot (BYOD módszere). Ez a mi iskoláinkban még kihasználatlan lehetőség. 2019-től a magyar iskolák többségében megoldott vagy megoldott lesz a megfelelő sávszélesség (persze, van még probléma). A tanulók okoseszközeit egyre jobban be lehetne vonni a tanítási-tanulási folyamatba az mlearning keretében.

A jó gyakorlat részét képezik azok a módszerek és tanulásszervezési eljárások, amelyek megvalósíthatók a hazai pedagógusok számára is: e-book felhasználása (pl. a készülő okostankönyvek), kérdésorientált/kutatásalapú tanulás, kollaboratív tanulás, problémafelvetésen alapuló tanulás, digitális történetmesélés. Ezek azok a lehetöségek, amelyek a SAMR-modell újra értelmezési szintjéig vezethetnek. De az e-book könyvekhez kapcsolódóan fontos lenne figyelembe venni azt, hogy a diákok maguk hozzanak létre ilyen tartalmat. A tanulók motivációját is növelheti a játékosítás (gamifikáció), amely elmozdulást jelent a digitális megoldások 
világa felé (pl. Socrative, Kahoot, LearningApps stb.). Az általam készített kismintás mérések adatai szerint ebben jelentős lemaradás van a hazai pedagógiai gyakorlatban.

\subsection{A kognitív kompetencia komponensei}

A digitális eszközök tanulókra vonatkozó kognitív hatásainak áttekintéséhez szükséges ennek a területnek az értelmező áttekintése. A pedagógusi fó tevékenységhez, a személyiségfejlesztéshez kapcsolódik a személyiség funkcionális modellje, amit Nagy (2000) dolgozott ki (2. ábra). Csányi Vilmos és Kampis György kutatásaira alapozva gondolta tovább a komponensrendszerelméletet. Eszerint az ember, mint személyiség és a csoport, mint a személyiséget létrehozó szocializációs és perszonalizációs rendszer is komponensrendszer. A rendszereknek van formája, kölcsönhatása és belső müködése. A rendszer módosulhat. Ennek a „módosulásnak” az elérése az egyik fő cél a pedagógiában.

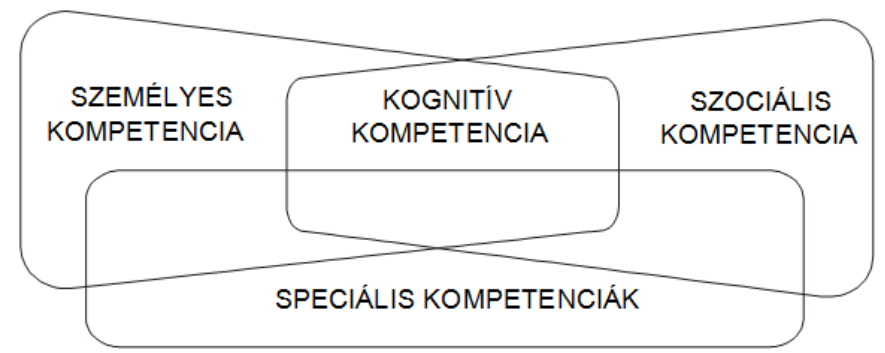

2. ábra. Egzisztenciális kompetenciák (Nagy, 2000, p. 35.)

A kompetenciát meghatározott funkció teljesítésére való alkalmasságnak tekinti Nagy (2000). Az alkalmasság döntések és kivitelezések által érvényesül, a döntések feltétele a motiváltság, a kivitelezések feltétele a képesség. Csaláné (2000) írja a 21. század és nevelés címü recenziójában, hogy „, a kompetenciák komponensei a képességek, az azokat felépitö készségek és a több ezer rutin mellett az ismeretek is. Rutinoknak nevezi a szerzö azoknak az ismereteknek a müködését, melyeket sebességük miatt nem tudunk tudatosan befolyásolni. Az ismeretek dominánsan leképezö, míg az operátorok dominánsan kivitelezö rendszerek. A rendszer nem merev, ami a müködés felöl nézve operátor, az a másik nézöpontból ismeret lehet."

A komplex kognitív képességeket részletezem Nagy5 (2000) csoportosítása alapján:

\footnotetext{
${ }^{5}$ Nagy (2000) könyvének 2. részében részletezi a kognitív kompetencia fejlesztésének (az értelmi nevelés, értelmezésre nevelés fejlesztése) kérdéseit pp. 65-175.
} 
- gondolkodás (része a nyelvtudás is a fogalmi gondolkodás eszközként)

○ konvertáló képesség: kódolás, tartalmi átalakítás

○ rendszerező képesség: összehasonlítás, azonosítás, besorolás, sorrendfelismerés, sorképzés, általánosítás (fogalomképzés), osztályozás

- logikai képesség (alapja a perceptuális predikció): tapasztalati következtetések, formális következtetések, kétváltozós logikai müveletek ${ }^{6}$

○ kombinatív képesség: Descartes-féle szorzatok, ismétléses variációk, ismétlés nélküli variációk, az összes ismétléses variáció, ismétléses kombinációk, ismétlés nélküli kombinációk, ismétléses permutációk, összes részhalmaz képzése

- kognitív kommunikáció

○ vizuális: ábraolvasás, ábrázolás

○ nyelvi: beszéd, beszédértés, írás, olvasás

○ formális: információk formulákba foglalása

- tanulás (a pszichikus módosulás főbb fajtái)

○ adaptáció

○ rendszerképződés

○ optimalizálódás

○ hierarchizálódás

- tudásszerzés (ismeretszerző képesség, alkotóképesség, problémamegoldó képesség)

○ ismeretszerzés: információ felvétel, információ feltárás

○ alkotóképesség: új produktum létrehozását eredményezi

\footnotetext{
${ }^{6}$ A modern logika eredményei bővítik a lehetőségeket.

${ }^{7}$ Egyéb csoportosítás: exploráció, észleléses tanulás; szándéktalan, szándékos; ismeretszerző, felfedező, értelmező, önálló, szociális; problémaorientált, érdeklődésalapú, alkotásközpontú, élményalapú, játékalapú, digitális
} 
○ problémamegoldás

$$
\begin{aligned}
& \text { alapvető szakaszainak készségei: hipotézisképzés, } \\
& \text { megfigyelés, értékelés, bizonyítás; } \\
& \text { összefüggésfajták szerint: feltétel(ek), } \\
& \text { következmény(ek), viszony /okság vagy együttjárás/ }
\end{aligned}
$$

A kognitív kompetencia a szociális, személyes és specifikus kompetenciák feltétele. Csaláné (2000) összegzéséből a következőket emelem ki: a faktoranalitikus eredmények alapján a kognitív kompetencia a kognitív komponensek (rutin, készség, ismeret), az azokból felépülő egyszerü kognitív képességek, majd az ezekből kialakuló komplex képességek rendszere (ezt részleteztem az előzőekben). A gondolkodás jelen van mindegyikben. A tanulási képesség az összes kognitív képesség rendszere. Az értelem a túlélés szolgálatában álló kognitív kompetencia, illetve információkezelő rendszer. Az intézményes értelmi nevelés célja az értelmezésre nevelés, amely spontán szocializációval nem érhető el. Valamennyi kompetencia alapja az érdekértékelő rendszer, amelynek segítségével döntéseket hozunk. Genetikus szinten az affektív apparátus, tapasztalati szinten a habitus, értelmező szinten a világtudat, önértelmező szinten az éntudat értékeli a döntéseinket.

\subsection{Forrásfeldolgozás Socrative és Redmenta segítségével}

A fenti elméleti keretnek a gyakorlatban történő IKT alkalmazással segített eleméire térek ki, azaz a digitális eszközök tanulókra vonatkozó kognitív hatásainak egy részét mutatom be. Az alapvető pedagógia cél a feladatokkal a történelmi kritikai gondolkodás kognitív elemeinek mérése, fejlesztése volt a gamifikáció lehetőségeit használva. A Socrative szavazórendszerben és a Redmentában nyújtott tanulói teljesítmények vizsgálata a 2018-as mérést is előkészítette, tanórán kívüli tanulási folyamatnál és tanórán használtam próbamérésre az alkalmazásokat.

A Socrative több funkciója közül a tesztelést alkalmaztam 2016-ban. A 20 itemes próbateszt kitöltésébe 35 középiskolás tanuló kezdett (15-18 évesek), de 29 eredmény volt használható. Az átlagos teljesítmény $50 \%$-os; 10 pontos tehát a megoldások átlaga. Egyéni visszajelzésre volt mód a Socrative összegző adatai segítségével. A kritikai gondolkodás kognitív elemeinek mérése volt az egyik cél a kutatással, a kísérleti kutatás fejlesztő moduljaihoz és a kimeneti teszthez használtam fel a kismintás mérésben alkalmazott feladatokat.

Az általam összeállított kritikai gondolkodás taxonómiára építettem a feladatsort. Ezek a következők: érvelés; érvelő szövegböl lényegkiemelés; következtetés forrás 
alapján; források kritikai elemzése; fogalom azonositása (képi információ, szöveg alapján); ábra, szöveg, táblázat, grafikon értelmezése; okok, célok feltárása.

Növelte a diákok tanórán kívüli motivációját, az eredményesebb kognitív tevékenységet a tesztek feldolgozása, az eredményekböl levont következtetések beépülhettek a tanítási-tanulási folyamatba. A tanulók kulcskompetenciái fejlődtek a következő területeken: anyanyelvi kommunikáció, idegen nyelvi kommunikáció, digitális kompetencia, hatékony, önálló tanulás. E vizsgálat is megerősítette, hogy nem önálló képesség a kritikai gondolkodás, hanem az általános kognitív képességek szituációtól függő készleteként értelmezhető.

A fejlesztés fókuszába az értelmező képelemzés áttekintése került a Redmentában alkalmazott feladatokkal. Ez egy feladatlapkészítő alkalmazás, amely a magyar fejlesztők meghatározása szerint „intelligens oktatási asszisztens”-ként használható. A Socrative-val összehasonlítva elmondható, hogy a Socrative szervere megbízhatóbb, a profitérdekeltség miatt (csak 1 „szoba” használata ingyenes) folyamatos a felület megújítása. A Redmenta nonprofit fejlesztésként jött létre, de a fejlesztői csapat egy része már más kutatásban vesz részt, időnként (pl. az adatok mentésekor) akadozik a müködés. Jelen időszakban próbálják a rendszer stabil müködését megoldani a fejlesztők néhány pedagógus bevonásával. Szerkesztett használati útmutatója nincs a felületnek, de a tanári munkát segítik a Facebook Redmenta tesztelöi csoportjában jelenleg is. 2015-ben hozta létre a csoportot Mérő Bálint, adminisztrátor, rajta kívül pedig Bordás Ádám és Visy Zoltán. A feladatkészítővel kapcsolatban folyamatosak a felhasználói visszajelzések, közel 1000 tagja van.

Az értelmező képelemzés lehetőségeit vizsgáltam a Redmentában. Vajda (2013) alapján (ő a tankönyvek képi forrásait vizsgálta) akkor tekinthető módszernek a képelemzés alkalmazása, ha a képhez szakmai szempontrendszert és didaktikai apparátust rendelünk. Az explicit (verbalizálás) képelemzés és az implicit (mögöttes tartalom feltárása) képelemzés együttesen alkotja az értelmezö képelemzés hátterét. Kérdések, feladatok, gyakorlatok jelentik a didaktikai apparátust a képek elemzésekor, ha ez nincs, akkor pusztán illusztrációnak tekinthető az adott képi elem. Képnek tekintem a vizuálisan feldolgozandó, a tanulót kódváltásra késztető forrásokat.

A 4 évfolyamos gimnáziumi kerettanterv kvalitatív tartalomelemzése alapján a történelmi kritikai gondolkodás kognitív elemeinek web 2.0-ás környezetben történő tesztelésénél e három elemre koncentráltam elsősorban a gyakorlatban (nem érintettem minden elemét):

- Különböző képek, plakátok, karikatúrák vizsgálata a történelmi hitelesség szempontjából. 
- Érvek gyüjtése feltevések mellett és ellen, az érvek kritikai értékelése.

- Kérdések megfogalmazása a források megbízhatóságára, a szerző esetleges elfogultságára, rejtett szándékaira vonatkozóan.

A kritikai gondolkodást befolyásoló kognitív folyamatok esetében az információfeldolgozás hatékonyságát, a képelemzést a következő tényezők befolyásolják (Bárdossyék 2002-ben szövegre alkalmazták):

- interaktív (intellektuális párbeszéd a képpel);

- reflektív (reagálások, visszajelzések a látottakra);

- monitorozó (az információk nyomon követése, figyelése);

- prediktív (jóslás, előfeltevés);

- aktív (tevékeny jelentésteremtés, befogadás);

- rekurzív (újraértelmezés, ellenőrzés)

- tentatív (a jelentést ideiglenesnek tekintő, változtató, korrigáló megértés).

A hatékony, értelmező képelemzést segíti Szabó - Kaposi (2017) módszertani anyaga a történelmi források feldolgozásához. Mivel a próbamérést a Redmentában karikatúrákkal végeztem, az erre vonatkozót emelem ki az írásukból, de a képelemzés egyéb területein is segítséget nyújt (kép, képregény, fénykép, térkép, plakát, film) az említett forrás. Ezt a módszertani anyagot is felhasználtam a fejlesztő modulok során.

Az értelmező képelemzés támogatására az operátorokra vonatkozó szavakat a mondatok elejére helyeztem:

- Fel kell tárni a karikatúra müfaji sajátosságait (pl. sürítettség, hasonlatok, mítoszok felhasználása; szórakoztatás, egyoldalúság).

- Azonosítani kell az ábrázolásmód és a szimbólumok jellegzetességeit.

- Fontos feltárni a vizuális jellegzetességeket (méret, színek, rajzolási technikák) és viszonyukat az ábrázolt személyhez, témához.

- Azonosítani, értékelni kell a megjelenő szerzői tendenciát és szándékot, értékítéletet, véleményt.

- Össze kell vetni a karikatúra által sugallt értékítéletet más típusú forrásokban található információkkal. 
Tehát az elemzést segítő szavak: feltárás, azonosítás, értékelés, összevetés. A kognitív folyamat dimenziójának kategóriai közül ezek elsősorban a megértésre, elemzésre és értékelésre vonatkoznak, ezt a kerettantervi tartalomelemzés is megerösítette.

A feladatok lehetséges típusai: feleletválasztós (egy jó válasz), feleletválasztós (több jó válasz), alternatív választás (igaz-hamis), kifejtős, rövid válasz, párosítós, sorrend. Az értelmező képelemzést tehát e feladattípusokból lehetett támogatni. A feladatok fejlesztésének algoritmusa az esetemben: elöször létrehozom online felület nélkül a fejlesztési céloknak megfelelően a feladatot, majd meg kell oldani az online változatú müködését. A történelmi kritikai gondolkodás kognitív elemeinek fejlesztése érdekében a következő feladattípusokat választottam: a feleletválasztós (egy jó válasz), kifejtős és rövid válasz.

A tanulók m-learning keretében az órán megosztott helyi internetes hálózat segítségével saját okostelefonjukon tudtak belépni a felületre. Ehhez két lehetőséget adtam regisztráció nélküli megoldásként: QR-kóddal azonnal a felületre tudtak belépni, vagy az általam megadott direktcímet használták a belépéshez a Redmenta felületén. A próbamérés (24 tanuló 58\%-os átlagos teljesítményt nyújtott) 2 karikatúrához kapcsolódott, amelyet korábbi tanulmányomban már bemutattam (Érsek, 2018).

A valódi előnye az m-learninggel támogatott tanítási-tanulási folyamatnak nem az eszközhasználati tevékenység, hanem tartalmi célok megvalósításának támogatása, a gondolkodás fejlesztése. A gimnáziumi 9-11. osztályos kerettanterv kvalitatív tartalomelemzése és a tanulási célkitüzések modell (a Bloom-taxonómia kétdimenziós modellje: Anderson, Krathwohl, 2001) összekapcsolásának eredményeképpen a korábban említettnél átláthatóbbak a történelmi kritikai gondolkodás kognitív folyamatai. Kutatási feladatként megoldottam, hogy a kétdimenziós modellbe jelenítettem meg (a tudás és kognitív dimenzióban is) a kerettantervben megjelenő történelmi kritikai gondolkodásra vonatkozó elemeket. Ezt nem tárgyalom a jelen tanulmány keretei között.

\section{NEO LMS}

Komenczi (2009) a tanítás és tanulás feltételrendszerének nevezi az elektronikus tanulási környezetet, meghatározó e rendszerben a virtuális osztályterem, sajátos interfész felület, ahol szervezett tudástartalom megosztása zajlik különbözö instrukciók és programok segítségével. A most vizsgált téma esetében ez a Neo LMS alkalmazás, ezt használták legkevésbé az általam mért mintában a diákok ( $\mathrm{N}=152 ; 2 \%)$, ebből következik, hogy a tanárok körében sem ismert.

A Neo LMS tehát e-learning keretrendszer, web 2.0 eszközként felhasználható a tanítási-tanulási folyamatban. Fülöp (2014) szerint „Az e-learning olyan 
számitógépes hálózaton keresztül elérhetö képzési forma, amely a tananyag feldolgozásához digitális médiumokat használ (DVD, CD-ROM, internet). A tanulási-tanitási folyamatot hálózaton keresztül müködö szoftver - keretrendszer segitségével szervezik meg. A keretrendszerekben helyezik el a tananyagot, itt történik a kommunikáció a diáktársak és a tutor (online oktatást segitö tanár) között, itt történik a konzultáció, a számonkérés is különbözö módszerek segítségével (tesztek, kooperativv, kollaborativ tanulást elösegitö kommunikációs felületek felhasználásával), illetve a tanulási folyamat menedzselése."

A Neo LMS felületén a tanulás során sorban kell haladni a lecke tanegységein, foglakozásain. Ezt adminisztrátorként a tanár beállíthatja. Az elméleti tudnivalók mellett a gyakorlati tapasztalatok szerzése is fontos, hisz a témával kapcsolatban az önálló tanulási tevékenység részeként egyéni keresés és feldolgozás is lehetséges. A plusz információk linkjei és a fájlok a közös felületen megoszthatók egymással.

A Neo LMS internetes portálként (https://www.neolms.com/ - 2019. 03. 08.) bárhonnan elérhetö, így a diákok nemcsak az iskolai környezetben tudnak tanulni. Használatához nincs szükség az átlagosnál több számítógép-használati ismeretre vagy külön szerverre. A szoftver letöltéseket sem igényel. A weblap magyar nyelvü (lehet angol nyelvü is a nyelvi kompetenciák fejlesztésére), ékezetes betükkel. A regisztrálásomkor 2014-ben 2000 tanulóig ingyenes volt a használat, jelenleg is így müködtethető az elektronikus osztálytermem. A most regisztrálók számára 400 fö számára ingyenes a használata. Ez megfelelő mennyiség egy átlagos tanári menedzselő munkához. A rendszer nem kötődik tantárgyhoz, csak egy keret, amelyet a tutor tölt ki tartalommal.

Kárpát 2014-ben készített ezzel kapcsolatban egy rövid összefoglalót: A Neo LMS egy tananyagtartalom szervező rendszer (LCMS). Segítségével „digitális” iskolát lehet létrehozni. A tanulók tankörökbe tudnak beiratkozni, akár többe is. A tanulócsoportok számára a tanár tananyagelemeket, a tantárgyhoz kapcsolódó kiegészítő információkat tud feltenni (ezek lehetnek, szövegek, képek, animációk, videoklippek, linkek stb.).

A rendszeren belül kommunikációs lehetöség van a tanárok-diákok és diákokdiákok között. A tankör blogja lehetőséget ad a tanulók írásainak, keresési eredményeinek, ötleteinek közzétételére, megvitatására. Adminisztrációs feladatokat is ellát a rendszer. Ha jelenléti órán használják a tanulók, akkor a jelenlévőket regisztrálni lehet. Egyéni tanulás esetén a tanár látja, hogy a diák hányszor használta a rendszert, és mikor lépett be utoljára.

A gyakorlás, ellenőrzés a különböző típusú tesztfeladatok, kérdőívek segítségével végezhető. A tanár által készített online tesztek eredményeit a pedagógus a feladat 
befejezésével megkapja a beállítástól függően, pontszámban, százalékban vagy osztályzatban. A rendszer gyüjti a tanulók eredményeit, és a naplóból megnézhetők, ellenőrizhetők. Az elkészített tesztek a hozzáférésre jogosult tanárok által a különböző csoportokban felhasználhatók. A teszt szerkesztése során beállítható a kezdés és befejezés időpontja, csak egyszer vagy többször is kitölthető. A kérdések nehézség szerint súlyozhatók.

Milyen módszertani megoldásokkal tudjuk elérni, hogy a digitális technológia hatékonyan szolgálja a nevelési - képzési célokat? A tanulási folyamatot saját igényeinkhez kell igazítani. Az alábbi tanulási tevékenységet végezhetik például a tanulók: iskolán kívüli adatgyüjtés, munkanapló készítése, a projekttermék elkészítéséhez szükséges munkatevékenység, kölcsönös visszajelzések, forrásfeldolgozás stb. Tanulásmenedzsment rendszerként használhatják a diákok a Neo LMS alkalmazást, aminek tehát saját online platformja van, amely biztosítja a kommunikáció helyét és eszközeit. A felületen lehetőség van megosztani dokumentumokat (pl. szöveget, képet stb.). Munkaformaként a kooperatív munka, pármunka és egyéni munka is lehetővé válik.

Egyéb digitális eszközök is használhatók a tanulási folyamat közben: videoszerkesztő eszközök, kollaborációs eszközként linkmegosztás, kommunikációs eszközként chat, digitális médiaeszközök (lap topok, digitális fényképezőgép, videokamera, asztali számítógép), interaktív tábla (a projekt, feladat bemutatására), mobileszközök (okostelefonok), videomegosztó oldal (You Tube), widget-ek (Google alkalmazások, eszközök pl.: Google Maps).

A tanulási folyamat során a tanulók együttmüködési készsége, kreativitása, kritikai gondolkodása fejlődhet. A kollaboratív munka során digitális eszközöknek és a web 2.0-ás szolgáltatásnak kiemelt szerepe lehet a tartalomfejlesztésben, együttmüködésben és megvalósításban. A tanulási folyamat során az IKT olyan alkalmazásait lehet megmutatni, amelyek normál órai kereteken belül nem lehetségesek.

A Neo LMS-sel történő tanítási-tanulási folyamat fejlődést hoz az IKT pedagógiai célú használata szempontjából. A tanulók tanulási attitüdjét pozitívan befolyásolja az itt végzett tevékenység. A didaktikai funkciója is jelentős, hisz alkalmas az érdeklődés felkeltése mellett új ismeretek korszerü átadására, lehetőséget kapnak elemzésre, rendszerezésre, gyakorlásra. A tanulók által elkészített és megjelenített információk hitelesekké, szemléletesekké válnak számukra, bővülnek ismereteik, képességeik. Fejleszthető szociális kompetenciájuk, az érzelmi intelligenciájuk, a kommunikációjuk, a szövegalkotásuk a Neo LMS használatával. Az eszközhasználati tevékenység mellett az igazi előny a nevelési és tartalmi célok mélyítésének lehetősége. 
A következő előnyökkel járhat a Neo LMS alkalmazása a tanár számára: elősegíti a pedagógusok szemléletváltását, bővíti a résztvevők szakmódszertani repertoárját, gyakorlati segítséget biztosít szaktárgyi témák feldolgozásához, lehetővé válik a nevelési-tanulási környezet újszerủ megoldásainak megismerése, a szakmai együttmüködések színtere biztosított lesz, a tanárnak rendelkeznie kell azokkal a pedagógiai és fejlesztő, támogató módszerekkel, melyek nélkülözhetetlenek a 21. századi készségek elsajátításához.

A következő előnyökkel járhat a Neo LMS alkalmazása a tanuló számára: a résztvevők kulcskompetenciái fejlödnek a következő területeken: anyanyelvi kommunikáció, idegen nyelvi kommunikáció (átállitható a nyelvi beállítás), digitális kompetencia, szociális kompetencia, kezdeményezőképesség (pl. a tudásmegosztásnál) hatékony, önálló tanulás. A 21. századi készségek fejlesztése lehetővé válik: ${ }^{8}$ tanulási és innovációs készségek (kreativitás és innováció, kritikai gondolkodás és problémamegoldás, kommunikáció és együttmüködés); információs, média- és technológiai készségek (információs mủveltség, médiaműveltség, információs és kommunikációs technológiai műveltség); életvezetési és karrierkészségek (rugalmasság és alkalmazkodóképesség, kezdeményezőkészség és önirányítás, társas és multikulturális készségek, teljesítmény és elszámoltathatóság, vezetői készségek és felelősségvállalás).

A fenti felsorolás alapján látható, hogy az elektronikus tanulási környezetnek számító web 2.0-ás eszköz (Neo LMS) és a 21. századi készségek között összefüggés van. E felület pedagógiai célú felhasználása a köznevelésben, felsőoktatásban is hozzájárulhat a digitális átállás ${ }^{9}$ támogatásához.

\footnotetext{
${ }^{8}$ Intel® Teach Program Essentials Tanfolyam Alapvető 21. századi készségek anyaga alapján

Forrás: Partnership for 21st Century Skills (www.21stcenturyskills.org). A felhasználás engedélyezve.

${ }^{9}$ E témáról bővebben ír Racsko (2017).
} 


\section{Felhasznált irodalom}

Anderson, L.W. (Ed.), Krathwohl, D.R. (Ed.), Airasian, P.W. Cruikshank, K.A., Mayer, R.E., Pintrich, P.R., Raths, J., \& Wittrock, M.C. (2001): A taxonomy for learning, teaching, and assessing: A revision of Bloom's Taxonomy of Educational Objectives (Complete edition). New York: Longman. Iowa State University CELT 2017. A Model of Learning Objectives. URL: http://www.celt.iastate.edu/wpcontent/uploads/2015/09/RevisedBloomsHandout-1.pdf (2018. 01. 21.)

Bárdossy Ildikó - Dudás Margit - Pethőné Nagy Csilla - Priskinné Rizner Erika (2002a): A kritikai gondolkodás fejlesztése - az interaktív és reflektív tanulás lehetőségei. Tanulási segédlet pedagógusok és pedagógusjelöltek számára. Pécsi Tudományegyetem, Pécs.

URL: http://pedtamop412b.pte.hu/files/tiny_mce/File/KG1.pdf (2015. 01. 20.)

Csala Istvánné Ranschburg Ágnes (2000): 21. század és nevelés. Recenzió. Új Pedagógiai Szemle, pp. 92-97. URL: https://bit.ly/2uoQfRr (2019. 03. 21.)

Érsek Attila (2014): A módszertani továbbfejlődés irányairól, avagy ami a minősítés után jön. A web 2.0 felhasználásának lehetőségei a tanításitanulási folyamatban. In: Tóth László (szerk.) (2014): Ellenőrzés a közoktatásban. Raabe Tanácsadó és Kiadó Kft., Budapest. F 6 pp. 1-27.

Érsek Attila (2015a): Megváltoztatja-e az Edu 2.0 a tanitási-tanulási folyamatokat, szokásokat? In: Kádár Judit - Szép Beáta - Nagy Krisztina - Zsámba Renáta (szerk.): International Strategies in Higher Education - Conference Proceedings. Eszterházy Károly College, Eger. (June 3-5, 2014) pp. 134-151.

Érsek Attila (2015b): A Történelemtanitás online folyóirat IKT vonatkozásokat tartalmazó írásai 2010 és 2015 között. Történelemtanítás Online történelemdidaktikai folyóirat, (L.) Új évfolyam VI. 3-4. szám. URL: http://www.folyoirat.tortenelemtanitas.hu/wpcontent/uploads/2016/02/06_03_08_Ersek.pdf (2018.01.07.)

Érsek Attila (2018) A történelmi kritikai gondolkodás kognitív elemeinek fejlesztési, tesztelési lehetőségei értelmező képelemzés segítségével web 2.0-ás tanulási környezetben. In: Agria Média 2017. Eger, Líceum Kiadó. pp. 91-97. 
Fülöp Hajnalka (2014) Hol tart ma az online oktatás Magyarországon? Modern Iskola, 2014. 2. szám URL: http://moderniskola.hu/cikk/hol-tart-maonline-oktatas-magyarorszagon (2015. 05.30.)

Jancsák Csaba (2019): Kutatási tényeken alapuló tananyagfejlesztés az MTASZTE Elbeszélt Történelem és Történelemtanitás Kutatócsoportban. Félidős szakmai beszámoló. MTA, URL: https://bit.ly/2U1KHee (2019. 03. 21.)

Kaposi József (2017): A történelmi gondolkodás és a képességfejlesztö feladatok. Történelemtanítás Online történelemdidaktikai folyóirat (LII.) Új folyam VIII. 1-2. szám URL: https://bit.ly/2Th1ntF (2019. 03. 19.)

Kárpát József (2014): EDU2.0 tananyagtartalom szervezö rendszer alkalmazása a középiskolában. http://goo.gl/n3AjWi (2015. 01. 31.)

Kojanitz László (2010): A kérdésorientált (inquiry based) történelemtanitás összekapcsolása az IKT adta lehetöségekkel. Iskolakultúra 9. sz. pp. 6581. URL: http://epa.oszk.hu/00000/00011/00150/pdf/2010-09.pdf (2018. 01. 16.)

Kojanitz László (2011). A forrásfeldolgozástól a kutatásalapú tanulásig. Történelemtanítás Online történelemdidaktikai folyóirat (XLVI.) Új folyam II. 4. szám URL: http://bit.ly/2CLiVtX (2018. 01. 07.)

Komenczi Bertalan (2009): Elektronikus tanulási környezetek. Gondolat Kiadó, Budapest.

Lai, Emily R. (2011): Critical Thinking and Pedagogy: Critical Thinking in Literary Studies. URL: http://bit.ly/2ndhtYm (2019. 02. 27.)

Lynch, Julianne (2002): What can we learn from McLuhan? Electronic communication technologies and the future of schooling. URL: http://bit.ly/2ACQsBo (2018.01.07.)

Nagy József (2000): XXI. század és nevelés. Osiris Kiadó, Budapest.

Pászka Imre (2016): A személyes történetek elméleti és módszertani kereteinek vázlata. MTA-SZTE Elbeszélt Történelem és Történelemtanítás Kutatócsoport. URL: https://bit.ly/2CumgMo (2019. 03. 21.)

Racsko Réka (2017): Digitális átállás az oktatásban. Gondolat Kiadó, Veszprém. Iskolakultúra-könyvek 52. https://doi.org/10.17717/IQKONYV.Racsko.2017 
Szabó Márta - Kaposi József 2017. Módszerek a források feldolgozásához.

URL: http://kaposijozsef.hu/hallgatoknak/20162017-tavasz/ (2018.

01. 07.) - Egyéb/A források feldolgozása.

Vajda Barnabás (2018): Bevezetés a történelemdidaktikába és a történelemmetodikába. Második kiadás. Selye János Egyetem Tanárképző Kar, Komárom.

Vajda Barnabás (2013): Mire valók a tankönyves képi történelmi források? Katedra. URL: http://bit.ly/2xwmz9n (2019. 02. 27.)

Z. Karvalics László (szerk.) (2009): Web 2.0 az oktatásban. INFONIA Alapítvány, Budapest. URL:

http://www.infonia.hu/webketto_az_oktatasban.pdf (2018. 01. 07.) 